\title{
Susam Fillodi Hastalığının Antalya illinde Yaygınlığı ve Bulunma Oranı
}

\section{Zahide ÖZDEMIR'}

\author{
' Adnan Menderes Üniversitesi, Ziraat Fakültesi, Bitki Koruma Bölümü, Aydın
}

Öz: Susam fillodi hastalığı susam (Sesamum indicum L.) verimini azaltan bir fitoplazma hastalığıdır. Hastalığın yaygınlığını ve bulunma oranını saptamak amacıyla 201/-2014 yılları arasında Antalya ilinde sörveyler yapılmıștır. Bu amaçla susam tarlalarına sezon boyunca 2 ile 5 kez sörvey yapılmıș ve tarla lokasyonları GPS ile ișaretlenmiștir. Tüm yıllara bakıldığında, hastalık susam hasadına yakın olan Ağustos ayının üçüncü haftasından itibaren hasada kadar en yüksek seviyede görülmekte ve yaygınlığı yüzde 100'e ulașmaktadır. Hastalık bulunma oranı ise ortalama olarak maksimum \% I'dir. Dört yıllık bu sörvey göstermektedir ki fillodi hastalığı Antalya ili için endemiktir. Sörvey alanlarında fillodi hastalığının susamda yaygın olduğu gözlemlenmiștir.

Anahtar Kelimeler: fitoplazma hastalıkları, susam fillodi, Sesamum indicum L.

\section{Disease Prevalence and Incidence of Sesame Phyllody in Antalya}

\begin{abstract}
Sesame phyllody is a phytoplasmal disease of sesame (Sesamum indicum L.) reducing the sesame yield. In order to determine prevalence and incidence of the disease, surveys were conducted in Antalya during $201 \mathrm{I}-2014$. For this purpose, surveys were carried out 2 to 5 times to sesame fields per growing season and locations were marked by GPS. In terms of all the years, toward the harvest period, from third week of August to harvest, the disease prevalence was the highest, up to the 100 percent. Maximum disease incidence in average was $I I$ percent. The four-year survey has shown that phyllody disease is endemic in Antalya. In the surveys, it was observed that phyllody was a widespread disease of sesame plants.
\end{abstract}

Keywords: phytoplasma diseases, sesame phyllody, Sesamum indicum $L$.

\section{GiRiș}

Susam fillodi hastalı̆̆ı, susam bitkisinin en önemli hastalıklarından birisidir. Ülkemiz dıșında hastalık dünyada susam yetiștirilen İran, İsrail, Hindistan, Pakistan, Tayland, Ürdün gibi ülkelerde büyük sorun yaratmaktadır (Klein, 1977; Salehi ve Izadpanah, 1992; Nakashima ve ark., 1995; Khan ve ark., 2007; Akhtar ve ark., 2009). Hastalıklı bitkiler sağlıklı tohum üretemediklerinden dolayı susam verimi doğrudan etkilenmektedir. Bitkiler normal çiçek olușturamamakta, bunun yerini küçük șekilsiz yapraklar almaktadır. Olușan tohumlar tohum kapsülü içerisinde çimlenmekte, bitki boğum araları kısalmakta, yaprak ve bitki boyunda küçülme ve kısalmalar görülmektedir (Klein, 1977; Salehi ve Izadpanah, I992; Akhtar ve ark., 2009). Fillodi hastalığı görülen bitkilerde 3 ana belirti tipi görülmektedir; fillodi; çiçeklerde petal yerine yaprakların olușması, virescence; așırı yeșillenme ve cadı-süpürgesi görünümüdür (Kersting, 1993). Hastalık etmeni patojen fitoplazmalar, floemde yașayan hücre duvarı olmayan bakterilerdir. Hastalık, bitkiden bitkiye vektör böceklerle tașınmaktadır. Bu vektörlerin bașında Homoptera takımından Cicadellidae familyasına ait bazı yaprak pireleri gelmektedir. Bunlar Orosius orientalis (Matsumura) [(syn=Orosius albicinctus) Distant] (Kersting, 1993; Esmailzadeh-Hosseini ve ark. 2007), Circulifer (=Neoaliturus) haematoceps (Mulsant and Rey) (Salehi ve Izadpanah, 1992). Türkiye'de hastalığın vektörü olarak Orosius orientalis ve C. haematoceps (Kersting, 1993; Bașpınar ve ark., 1993; Sertkaya ve ark., 2007; İkten ve ark., 20I4) olarak rapor edilmiștir. Hastalık etmeni fitoplazmalar Orosius orientalis bireylerinde moleküler olarak tespit edilmiștir (Sertkaya ve ark., 2007; Özdemir ve ark., 20I3, 20I4; Özdemir, 20I7; Ikten ve ark., 20I4).
Hastalığın bulașmasında tohumların önemli olmadığı, böcek vektörlerin yanı sıra, küsküt gibi yarı parazit yabancı otlarla da patojenin tașınabildiği Akhtar ve ark. (2009) tarafından bildirilmiștir.

Akdeniz Bölgesi boyunca susam fillodi hastalığı üzerine ilk çalışma 1990 yılında Kersting (1993) tarafından yapılmıștır. Kersting (1993) hastalığın Antalya ve Silifke'de Adana, Hatay, Urfa ve Gaziantep'ten çok daha fazla bulunduğunu belirtmiștir. Antalya ili susam üretimi bakımından 2015 verilerine göre Türkiye'de ilk sırada yer almaktadır (Tan, 20I5). Bununla birlikte susam üretimi az da olsa azalmaya bașlamıș ve yüzde 20'lik üretimle Manisa ilinden sonra \%/8'lik üretimle ikinci sıraya gerilemiștir (Seçer, 20l6). Bir fitoplazma hastalığı olan fillodi hastalığının Antalya'daki durumu ile ilgili bazı çalıșmalar yapılmıș olup bu çalıșmalarda daha çok hastalığa neden olan fitoplazmaların belirlenmesine ağırlık verilmiștir (Çatal ve ark., 20l3; Ikten ve ark 20l4; Özdemir ve ark., 2013, 20I4; Özdemir, 20I7). Antalya'da 20II yılında ilçelere göre değișmekle birlikte hastalığın bulunma oranı \%50'nin üzerinde olduğu bildirilmiștir (Ilkten ve ark., 20II). Ancak hastalığın Antalya'da susam alanlarındaki yaygınlığı ve bulunma oranı ile ilgili detaylı güncel bir çalıșma bulunmamaktadır. Bu çalıșma susam fillodi hastalığının Antalya ilinde susam yetiștiriciliğinde yaygınlığı ve bulunma oranını tespit etmek amacıyla yapılmıștır.

Sorumlu Yazar: zozdemir@adu.edu.tr

Bu çalısma TUBiTAK I I006/4 no'lu proje kapsamında desteklenmiștir.

Geliș Tarihi: 20 Eylül 2017

Kabul Tarihi: 31 Mayıs 2018 


\section{MATERYAL ve YÖNTEM}

Hastalığın bulunma oranını saptamak üzere 20II-2014 yıllarında 4 yıl boyunca Antalya ili susam yetiștirilen alanlara sörvey yapılmıștır. Sörveyler ikinci ürün susam ekim üretim dönemi boyunca Temmuz- Eylül aylarında Antalya'nın Tașağıl, Çolaklı, Manavgat, Evrenseki ilçe ve beldelerinde gerçekleștirilmiștir. Sörvey alanlarının 116 adet GPS lokasyonları GPSI-I I6 șeklinde kaydedilmiștir. Șekil I'de örneklerin alındığı GPS lokasyonları görülmektedir. Fillodi hastalığının yaygınlığı ve bulunma oranı dekara en az 100 bitki tarlanın köșelerinden ve ortasından rastgele sayılarak hastalıklı ve sağlıklı bitki sayısı olarak kaydedilmiștir. Dört yıllık sörvey çalıșmalarını temsilen $201 \mathrm{I}$ ve 2013 yıllarına ait veriler ayrıntılı olarak sırasıyla Çizelge I-4 ve Çizelge 5-9'da verilmiștir. Sörvey alanlarından toplanan bitkilerde fitoplazma varlığı PCR ve PCR-RFLP moleküler tanılama yöntemleri ile daha önce belirlenmiștir (Özdemir, 2017).

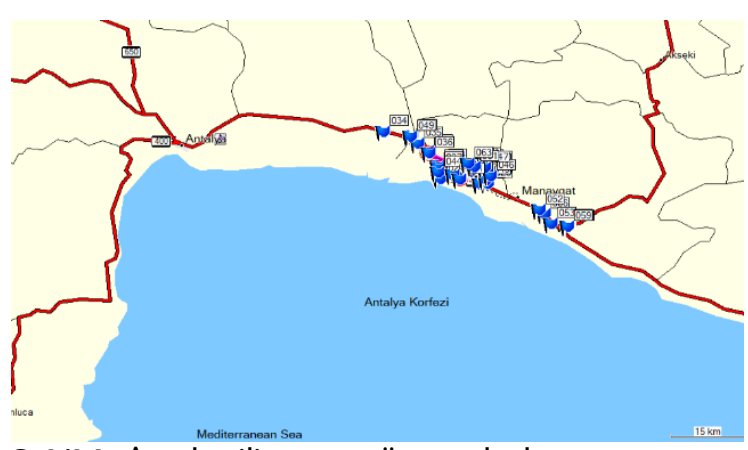

Șekil I. Antalya ili susam sörvey alanları

\section{BULGULAR ve TARTIȘMA}

Illk hastalık sörveyine 29 Temmuz $201 \mathrm{l}$ tarihinde bașlanmıștır. İkinci ve 3. sörveyler 10-II Ağustos 201। tarihinde 4. ve son sörvey 25 Ağustos $201 \mathrm{l}$ tarihinde yapılmıștır (Çizelge I-4). Sörveyler hastalık yaygınlığı

Çizelge I. Susam fillodi hastalığının bulunma oranı (29.07.20I I). I. Sörvey

\begin{tabular}{|c|c|c|c|c|c|}
\hline Tarla Sayısı & $\begin{array}{l}\text { Taranan } \\
\text { Bitki Sayısı }\end{array}$ & $\begin{array}{l}\text { Hastalıklı } \\
\text { Bitki Sayısı }\end{array}$ & $\begin{array}{l}\text { Hastalık } \\
(\%)\end{array}$ & Lokasyon' & $\begin{array}{l}\text { Alan } \\
\text { (Da) }\end{array}$ \\
\hline I & 600 & 22 & 4 & Tașağı| $\left.\right|^{2}$ & 3.5 \\
\hline 2 & 600 & 15 & 3 & Tașağıl & 6 \\
\hline 3 & 700 & 0 & 0 & Tașağıl & 14 \\
\hline 4 & 500 & 3 & I & Evrenseki & 5 \\
\hline 5 & 650 & 71 & II & Evrenseki & 5 \\
\hline Toplam & & & & & 33.5 \\
\hline
\end{tabular}

I: Bu lokasyonların GPS no.ları kaydedilmemiștir. ${ }^{2}$ : Birinci tarla Koskos Mehmet isimli üreticinin tarlası olarak not edilmiștir ve 2. sörveyde (Çizelge 3) bu tarlaya tekrar sörvey yapılmıștır.

Çizelge 2. Susam fillodi hastalığının bulunma oranı (I0.08.20II). 2. Sörvey

\begin{tabular}{|c|c|c|c|c|c|}
\hline Tarla Sayısı & $\begin{array}{l}\text { Taranan } \\
\text { Bitki Sayısı }\end{array}$ & $\begin{array}{l}\text { Hastalıklı } \\
\text { Bitki Sayısı }\end{array}$ & $\begin{array}{l}\text { Hastalık } \\
(\%)\end{array}$ & Lokasyon & $\begin{array}{l}\text { Alan } \\
(\mathrm{Da})\end{array}$ \\
\hline I & 400 & 58 & 15 & Tașağıl & 3.5 \\
\hline 2 & 750 & 84 & II & GPS004 & 7 \\
\hline 3 & 600 & 0 & 0 & GPS005 & 6 \\
\hline 4 & 400 & 0 & 0 & GPS006 & 4 \\
\hline 5 & 1200 & 0 & 0 & GPS007 & 12 \\
\hline 6 & 100 & 6 & 6 & GPS008 & I \\
\hline Toplam & & & & & 33.5 \\
\hline
\end{tabular}

': Bu lokasyonun GPS no.su kaydedilmemiștir, Koskos Mehmet isimli üreticinin tarlası olarak not edilmiștir ve Çizelge 2'deki birinci tarladır.

Çizelge 3. Susam fillodi hastalığının bulunma oranı (I I.08.20II). 3. Sörvey

\begin{tabular}{|c|c|c|c|c|c|}
\hline Tarla Sayısı & $\begin{array}{l}\text { Taranan } \\
\text { Bitki Sayısı }\end{array}$ & $\begin{array}{l}\text { Hastalıklı } \\
\text { Bitki Sayısı }\end{array}$ & $\begin{array}{l}\text { Hastalık } \\
(\%)\end{array}$ & Lokasyon & $\begin{array}{l}\text { Alan } \\
(\mathrm{Da})\end{array}$ \\
\hline $\mathrm{I}$ & 450 & 17 & 4 & GPS009 & 4 \\
\hline 2 & 1000 & 56 & 6 & GPSOIO & 10 \\
\hline 3 & 1000 & 0 & 0 & GPSOII & 12 \\
\hline 4 & 1600 & 64 & 4 & GPSOI2 & 22 \\
\hline 5 & 200 & 0 & 0 & GPSOI 3 & 1.5 \\
\hline 6 & 600 & 2 & 0 & GPSOI4 & 5 \\
\hline 7 & 400 & 2 & I & GPSOI 5 & 4 \\
\hline 8 & 1050 & 46 & 4 & GPSOI 6 & 20 \\
\hline 9 & 800 & 7 & I & GPSOI7 & 8 \\
\hline 10 & 1300 & 89 & I & GPSOI 8 & 15 \\
\hline Toplam & & & & & 101.5 \\
\hline
\end{tabular}


Çizelge 4. Susam fillodi hastalığının bulunma oranı (25.08.20II). 4. Sörvey

\begin{tabular}{|c|c|c|c|c|c|}
\hline Tarla Sayısı & $\begin{array}{l}\text { Taranan } \\
\text { Bitki Sayısı }\end{array}$ & $\begin{array}{l}\text { Hastalıklı } \\
\text { Bitki Sayısı }\end{array}$ & $\begin{array}{l}\text { Hastalık } \\
(\%)\end{array}$ & Lokasyon & $\begin{array}{l}\text { Alan } \\
(\mathrm{Da})\end{array}$ \\
\hline $\mathrm{I}$ & 300 & 23 & 8 & GPS20 & 3 \\
\hline 2 & 400 & 44 & II & GPS2I & 4 \\
\hline 3 & 800 & 82 & 10 & GPS22 & 9 \\
\hline 4 & 1450 & 81 & 6 & GPS23 & 12 \\
\hline 5 & 900 & 40 & 4 & GPS24 & 9 \\
\hline 6 & 350 & 17 & 5 & GPS25 & 3 \\
\hline 7 & 1200 & 27 & 2 & GPS26/0I I & 12 \\
\hline 8 & 1000 & 36 & 6 & GPS27/0I 2 & 22 \\
\hline 9 & 1250 & 69 & 6 & GPS28 & 22 \\
\hline 10 & 300 & 2 & I & GPS30 & 0.5 \\
\hline II & 1300 & 14 & I & GPS3I & 10 \\
\hline 12 & 700 & 23 & 3 & GPS32 & 5 \\
\hline Toplam & & & & & 111.5 \\
\hline
\end{tabular}

bakımından değerlendirildiğinde 29 Temmuz tarihli sörveyde gezilen arazi alanı ve sayısı az olmakla birlikte hastalık, tarlaların \%80'inde bulunmaktadır. Çizelge 2 ve 3 birleștirildiğinde gezilen tarla sayısı 15 tarlada 10'unda hastalık görüldüğü bulunmuștur. $\mathrm{Bu}$ da yaklașı \%70 oranında hastalığın yaygın olduğunu göstermektedir. Illk sörveyde taranan Koskos Mehmet adlı üreticinin tarlasında \%4 oranında hastalık görülürken hastalık 12 gün sonraki ikinci sörveyde \% I5'e varan bir hastalık artıșı görülmüștür. Çizelge 4'de ise son sörveyin sonuçları itibariyle \% 100 oranında hastalık görülmektedir. Onbir Ağustos 20II tarihinde GPSOII ile ișaretli alanda hiç hastalık bulunmazken iki hafta sonra aynı tarlada \%3 oranında hastalık saptanmıștır (GPS26, Çizelge 4). Son sörveyde ise hastalık bulunma oranı \% I ile II arasında değișmektedir (Çizelge 4). Bu rakamlar düșük gibi görünse de hastalıklı bitkilerde neredeyse hiç kapsül olușumu gözlemlenmemiș ya da kapsül tutanlarda ise kapsüllerin erkenden çatladığı ve içinde anormal șekilli tohumların olduğu görülmüștür. Bu da susam verimini doğrudan düșürmektedir (Kersting, 1993).

Hastalık sörveyi 2012 yılında susam yetiștirme dönemi ortalarında ve hasat zamanına yakın yapılmıștır. Hastalık yaygınlığının diğer yıllara göre az bir farkla daha az yaygın olduğu görülmektedir (\%97) ancak hastalık bulunma oranı bakımından 201 I ve 2014 yılları ile benzer șekilde en fazla yüzde I I civarındadır (Çizelge 10).

Antalya ili susam tarlalarında 2013 yılında susam fillodi hastalığının varlığı ve hastalık bulunma oranı, susam ekim dönemi boyunca yapılan 5 sörveyle belirlenmiștir (Çizelge 5-9). Genel olarak çiçeklenme dönemi öncesinde susam bitkilerinde fillodi belirtisi görülmemiștir. Bu yıl geçen iki yıla göre ilk sörvey tarihi erken yapılmıștır (Çizelge I0) ancak hastalık bașlangıcı 10 tarlanın 8'inde görülmüștür (Çizelge 5). İlk sörvey ile ikinci sörvey arasında hastalık yüzdesi bakımından fazla bir fark bulunmamıștır (Çizelge 5-6). Hastalık yüzdesindeki artıș ise Ağustos'un 3. haftasında yapılan 4. sörveyde ve hasada yakın yapılan 5. sörveyde olmuștur (Çizelge 8-9). Son iki sörveyde, hastalığın sörvey yapılan tüm tarlalarda bulunduğu görülmektedir ve son sörveyde de hastalık \%20 oranlarına kadar ulașmıștır (Çizelge 8-9).
Hastalık ilk kez susam yapılan alanlarda görülebilmektedir. Örneğin GPS75 nolu tarlada susam ekimi ilk defa yapılmıștır (üreticiden bilgi alınmıștır) ve bu tarlada ilk iki sörveyde hiç hastalık görülmemesine rağmen son sörveyde yüzde 10'a yakın hastalık bulunmuștur. Aynı zamanda GPS75, lokasyon olarak 2012 yılında hastalığın görüldüğü GPS33 ve GPS34 nolu lokasyonlara yakındır ancak bu lokasyonlarda bu yıl susam ekimi yapılmamıștır. GPS09 nolu lokasyonda susam ekim alanı azalmasına rağmen hastalığın en șiddetli ve her yıl görüldüğü alanlardan bir tanesi olarak tespit edilmiștir.

Hastalık sörveyi, 2014 yılında 20II-20I3 sörveylerine göre hastalığın en fazla görüldüğü dönem itibariyle yapılmıștır. Bu dönemde hastalık yaygınlığı yüzde 100 ve bulunma oranı \%0 ile 10 arasında değișmiștir (Çizelge 10).

Antalya ilinde 2011-2014 yıllarında yapılan tüm sörvey çalıșmaları Çizelge 10'da özetlenmiștir. Sörvey yapılan alanların tamamına yakın bir kısmında susam fillodi hastalığı görülmektedir. Șekil 2'de șiddetli derecede fillodi hastalığı görülen bir susam tarlası görülmektedir. Dört yıllık bu sörvey ișaret etmektedir ki fillodi hastalığı Antalya ili için endemiktir. Susam ekim dönemi içerisinde hastalığın en fazla görüldüğü dönem yaklașık olarak Ağustos ayının üçüncü haftasına rastlamaktadır. Bașpınar ve ark. (1993) Adana'da 199I yılında yaptıkları çalıșmada 25 Haziran'da ekilen yazlık susamda ilk hastalık çıkıșının Ağustos ayı bașında olduğunu belirtmișlerdir ve hastalığın 4 Eylül civarında en fazla olduğunu bulmușlardır. Aynı bölgede Sertkaya ve ark. (1997) tarafından yapılan bir çalıșmada Orosius orientalis'in de Circulifer haematoceps gibi hastalığın vektörü olduğu, hastalığın Ağustos ayından itibaren görülme oranının arttığı, genel olarak \%।-4 arasında değișmekle birlikte Gölmarmara, Muganlı-57 ve Özberk-82 susam çeșitleri arasında enfeksiyon oranı bakımından önemli bir fark belirlenmediği bildirilmiștir. Görülmektedir ki hastalık, Doğu Akdeniz'de susam ekim tarihi de dikkate alındığında yaklașık aynı zamanlarda en fazla görülmektedir ve hasada kadar devam etmektedir 
Çizelge 5. Susam fillodi hastalığının bulunma oranı (I7.07.20I3). I. Sörvey

\begin{tabular}{llllll}
\hline Tarla SayıSı & $\begin{array}{l}\text { Taranan } \\
\text { Bitki Sayıs }\end{array}$ & $\begin{array}{l}\text { Hastalıklı } \\
\text { Bitki Sayısı }\end{array}$ & $\begin{array}{l}\text { Hastalık } \\
(\%)\end{array}$ & $\begin{array}{l}\text { Lokasyon } \\
(\mathrm{Da})\end{array}$ & $\begin{array}{l}\text { Glan } \\
\text { GPS75 }\end{array}$ \\
\hline 1 & 690 & 0 & 0 & GPS76 & 2 \\
2 & 300 & 1 & 0 & GPS77 & 10 \\
3 & 730 & 4 & 1 & GPS78 & 1 \\
4 & 360 & 2 & 1 & GPS79 & 14 \\
5 & 840 & 1 & 0 & GPS80 & 17 \\
6 & 1264 & 12 & 1 & GPS8I & 40 \\
7 & 3300 & 0 & 0 & GPS60 & 5.5 \\
8 & 1311 & 3 & GPS6I & 8 \\
9 & 3300 & 2 & 0 & GPS82 & 2.5 \\
10 & 950 & 2 & 0 & & 106 \\
Toplam & & & 0 & & \\
\hline
\end{tabular}

Çizelge 6. Susam fillodi hastalığının bulunma oranı (3I.07.20I3). 2. Sörvey

\begin{tabular}{llllll}
\hline Tarla Sayısı & $\begin{array}{l}\text { Taranan } \\
\text { Bitki Sayısı }\end{array}$ & $\begin{array}{l}\text { Hastalıklı } \\
\text { Bitki Sayısı }\end{array}$ & $\begin{array}{l}\text { Hastalık } \\
(\%)\end{array}$ & $\begin{array}{l}\text { Alan } \\
\text { (Da) }\end{array}$ \\
\hline I & 1000 & 0 & 0 & GPS75 & 6 \\
2 & 500 & 0 & 0 & GPS83 & 3 \\
3 & 350 & 0 & 0 & GPS84 & 2 \\
4 & 950 & 6 & 1 & GPS85 & 9.5 \\
5 & 490 & 12 & 3 & GPS09 & 2.5 \\
6 & 360 & 1 & 0 & GPS86 & 4 \\
7 & 380 & 5 & 1 & GPS82 & 2.5 \\
8 & 1915 & 16 & GPS28 & 26 \\
Toplam & & & & & 55.5 \\
\hline
\end{tabular}

Çizelge 7. Susam fillodi hastalığının bulunma oranı (I3.08.20I3). 3. Sörvey

\begin{tabular}{|c|c|c|c|c|c|}
\hline Tarla Sayısı & $\begin{array}{l}\text { Taranan } \\
\text { Bitki Sayısı }\end{array}$ & $\begin{array}{l}\text { Hastalıklı } \\
\text { Bitki Sayısı }\end{array}$ & $\begin{array}{l}\text { Hastalık } \\
(\%)\end{array}$ & Lokasyon & $\begin{array}{l}\text { Alan } \\
(\mathrm{Da})\end{array}$ \\
\hline $\mathrm{I}$ & 530 & II & 2 & GPS83 & 3 \\
\hline 2 & 405 & 0 & 0 & GPS84 & 2 \\
\hline 3 & 50 & 5 & 10 & GPS88 & 0.5 \\
\hline 4 & 1040 & 29 & 3 & GPS85 & 9.5 \\
\hline 5 & 315 & 14 & 4 & GPS09 & 2.5 \\
\hline 6 & 640 & 0 & 0 & GPS52 & 7 \\
\hline 7 & 465 & 0 & 0 & GPS06 & 4 \\
\hline 8 & 620 & 6 & 1 & GPS53 & 8 \\
\hline 9 & 860 & 0 & 0 & GPS07 & 8 \\
\hline 10 & 245 & 8 & 3 & GPS08 & 1.5 \\
\hline II & 180 & 2 & 1 & GPS54 & 0.75 \\
\hline 12 & 100 & 0 & 0 & GPS89 & I \\
\hline 13 & 120 & 0 & 0 & GPS55 & 0.5 \\
\hline 14 & 310 & 0 & 0 & GPS90 & 4 \\
\hline Toplam & & & & & 52.25 \\
\hline \multicolumn{6}{|c|}{ Çizelge 8. Susam fillodi hastalı̆ının bulunma oranı (22.08.20I3). 4. Sörvey } \\
\hline \multirow[t]{2}{*}{ Tarla Sayısı } & Taranan & Hastalıklı & Hastalık & Lokasyon & Alan \\
\hline & Bitki Sayısı & Bitki Sayısı & $(\%)$ & & $(\mathrm{Da})$ \\
\hline I & 710 & 25 & 4 & GPS75 & 6 \\
\hline 2 & 160 & 17 & 11 & GPS9I & I \\
\hline 3 & Hasat & - & - & GPS88 & 0.5 \\
\hline 4 & 225 & 13 & 6 & GPS09 & 2.5 \\
\hline 5 & 436 & 29 & 7 & GPS92 & 3 \\
\hline 6 & Hasat & - & - & GPS77 & 10 \\
\hline 7 & 440 & 23 & 5 & GPS76 & 2 \\
\hline 8 & 665 & 35 & 5 & GPS37 & 3 \\
\hline Toplam I & & & & & 17.5 \\
\hline
\end{tabular}

': Sörvey yarım gün yapılmıștır. Hasat edilen alanlar toplam alana dahil edilmemiștir. 
Çizelge 9. Susam fillodi hastalığının bulunma oranı (09.09.20।3). 5. Sörvey

\begin{tabular}{|c|c|c|c|c|c|}
\hline Tarla Sayısı & $\begin{array}{l}\text { Taranan } \\
\text { Bitki Sayısı }\end{array}$ & $\begin{array}{l}\text { Hastalıklı } \\
\text { Bitki Sayısı }\end{array}$ & $\begin{array}{l}\text { Hastalık } \\
(\%)\end{array}$ & Lokasyon & $\begin{array}{l}\text { Alan } \\
(\mathrm{Da})\end{array}$ \\
\hline I & 745 & 70 & 9 & GPS75 & 6 \\
\hline 2 & 525 & 100 & 19 & GPS83 & 3 \\
\hline 3 & 370 & 74 & 20 & GPS84 & 2 \\
\hline 4 & Hasat ${ }^{1}$ & - & - & GPS85 & 9.5 \\
\hline 5 & 539 & 86 & 16 & GPS92 & 3 \\
\hline 6 & 565 & 74 & 13 & GPS09 & 2.5 \\
\hline 7 & Hasat & - & - & GPS86 & 4 \\
\hline 8 & 905 & 14 & 2 & GPSI04 & 4 \\
\hline 9 & Hasat & - & - & GPS28 & 26 \\
\hline 10 & 611 & 33 & 5 & GPS82I & 2.5 \\
\hline II & 802 & 38 & 5 & GPS6II & 8 \\
\hline Toplam² & & & & & 31 \\
\hline
\end{tabular}

': Bu tarlalarda susam hasadı bașlamıștır. Hasat edilen alan az olduğu için sörvey yapılmıștır. 2: Hasat edilen alanlar toplam alana dahil edilmemiștir.

Çizelge 10. Antalya ilinde susam fillodi hastalığının 20 I I-20I4 yıllarında yaygınlığı ve bulunma oranı

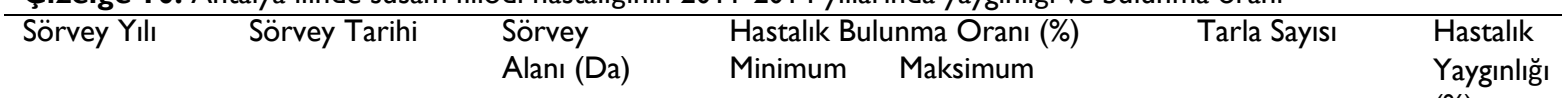

(\%)

\begin{tabular}{|c|c|c|c|c|c|c|}
\hline 2014 & $26.08 .20 \mid 4$ & 68.5 & 0 & 6 & 5 & 100 \\
\hline 2014 & 27.08 .2014 & 87.5 & 1 & 10 & 6 & 100 \\
\hline 2013 & 17.07 .2013 & 106.0 & 0 & I & 10 & 80 \\
\hline 2013 & 31.07 .2013 & 55.5 & 0 & 3 & 8 & 62.5 \\
\hline 2013 & 13.08 .2013 & 52.3 & 0 & 10 & 14 & 92.8 \\
\hline 2013 & 22.08 .2013 & 17.5 & 4 & II & 8 & 100 \\
\hline 2013 & 09.09 .2013 & 31.0 & 2 & 20 & II & 100 \\
\hline 2012 & 15.08 .2012 & 89.3 & 0 & 8 & 10 & 90 \\
\hline 2012 & 16.08 .2012 & 123.8 & 0 & 4 & 15 & 46.7 \\
\hline 2012 & 06.09 .2012 & 98.5 & 0 & II & II & 97.3 \\
\hline 2011 & 29.07.20II & 33.5 & 0 & II & 5 & 80 \\
\hline 2011 & $|0.08 .20| \mid$ & 33.5 & 0 & 15 & 6 & 50 \\
\hline 2011 & | I.08.20| | & 101.5 & 0 & 6 & 10 & 80 \\
\hline 2011 & 25.08 .2011 & 111.5 & I & II & 12 & 100 \\
\hline
\end{tabular}

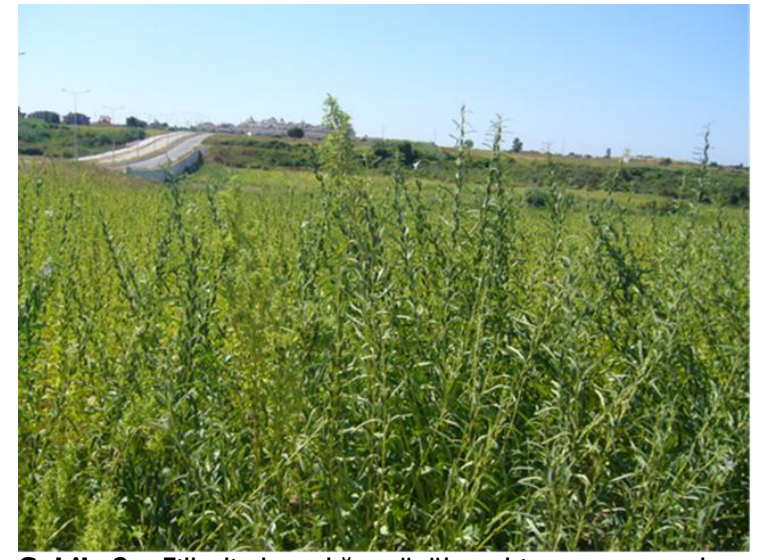

Șekil 2. Fillodi hastalığı görülen bir susam tarlası. Fotoğraf 25.08.20II'de Antalya'da çekilmiștir

Sörvey yapılan alanlarda bitki gelișim dönemleri farklı olmasına rağmen çiçeklenme öncesi dönemde fillodi hastalığı belirtilerine rastlanmamıștır. Kersting (1993)'in çalıșmasından sonra, bölgede, hastalık yaygınlığı ve bulunma oranı üzerine uzun yıllar sonra yapılan bu çalıșmada Antalya'da hastalığın yoğun olarak görüldüğü ortaya çıkmıștır

\section{SONUÇ}

$\mathrm{Bu}$ çalıșma ile Antalya ilinde susam fillodi hastalığının yaygınlığı ve bulunma oranı belirlenmiștir. Dört yıllık sörvey süresi boyunca hastalığın her yıl görülmesi hastalığın Antalya ilinde endemik olduğunu göstermektedir. Hastalık bulunma oranı tüm yıllara bakıldığında 2013 yılı hariç ortalama olarak maksimum \% I0 civarındadır. Gözlemlere dayalı olarak hastalık belirtileri çiçeklenme sonrasında ortaya çıkmaktadır. Hastalık yaygınlığının en yüksek seviyelere ulaștığı dönem Ağustos ayının üçüncü haftasından hasada kadar olan dönemdir. Sörveylerde fillodi hastalığının susamda verimi azaltan bașlıca ve en yaygın hastalık olduğu gözlemlenmiștir. Bu hastalıkla gerek kimyasal gerekse biyolojik olarak doğrudan bir mücadele yöntemi bulunmamaktadır. Susam ekim döneminin mümkün olduğunca erkene alınması ve/veya vektör böceklerle mücadele bu hastalıktan dolayı olușacak verim kayıplarını azaltmada yardımcı olabilecektir. 


\section{TEȘEKKÜR}

$\mathrm{Bu}$ çalıșma TÜBITAK II0OI4 No.lu projenin bir bölümünden yapılmıștır. Sörveyler boyunca yardımcı olan Akdeniz Üniversitesi Tarla Bitkileri Bölümü yüksek lisans öğrencileri Alper Adak, Hasan Topuz, Sezgim Toprak ve stajyer öğrencilerine teșekkür ederim.

\section{KAYNAKLAR}

Akhtar KP, Sarwar G, Dickinson M, Ahmad M, Haq MA, Hameed S, lqbal MJ (2009) Sesame phyllody disease: its symptomatology, etiology, and transmission in Pakistan. Turkish Journal of Agriculture and Forestry 33: 477-486.

Bașpınar H, Korkmaz S, Önelge N, Çınar A, Uygun N, Kersting $U$ (1993) Studies on citrus stubborn disease and sesame phyllody in sesame and their related leafhopper vectors. The Journal of Turkish Phytopathology 22: 1-8.

Catal M, Ikten C, Yol E, Üstün R, Uzun B (2013) First report of a I6SrIX group (Pigeon Pea Witches'Broom) phytoplasma associated with sesame phyllody in Turkey. Plant Disease, 97: 835,

Esmailzadeh-Hosseini SA, Mirzaie A, Jafari-Nodooshan A, Rahimian H (2007) The first report of transmission of a phytoplasma associated with sesame phyllody by Orosius albicinctus in Iran, Australasian Plant Disease Notes 2: 33-34.

Ikten C, Yol E, Catal M, Uzun B (20II) Frequency distribution of sesame phyllody disease associated with phytoplasmas in Antalya province of Turkey. Phytopathogenic Mollicutes, I (2): I0I-I02.

Ikten C, Catal M, Yol E, Ustun R, Furat S, Toker C, Uzun B (20l4) Molecular identification, characterization, and transmission of phytoplasma associated with sesame phyllody in Turkey. European Journal of Plant Pathology 139: 217-229.

Kersting $U$ (1993) Symptomatology, etiology and transmission of sesame phyllody in Turkey. The Journal of Turkish Phytopathology 22: 47-54.

Khan AJ, Bottner K, Al-Saadi N, Al-Subhi AM, Lee I-M (2007) Identification of phytoplasma associated with witches' broom and virescence diseases of sesame in Oman. Bulletin of Insectology 60: 133-134.

Klein M (1977) Sesame phyllody in Israel. Phytopathologische Zeitschrift 88: I65-I7I.

Nakashima K, Hayashi T, Chaleeprom W, Wongkaev P, Sirithorn $P$ (1995) Detection of DNA of phytoplasmas associated with phyllody disease of sesame in Thailand. Annals of the Phytopathological Society of Japan 61: 519-528.

Salehi M, Izadpanah K (1992) Etiology and transmission of sesame phyllody in Iran. Journal of Phytopathology 135: 37-47.

Sertkaya G, Satar S, Kersting U (1997) Farklı susam çeșitlerinde Circulifer haematoceps (M.-R.) ve Orosius orientalis (Mats.) (Homoptera: Cicadellidae)'in populasyon dalgalanmalarının saptanması. Ç.Ü. Ziraat Fakültesi Dergisi: I2(2): 8I-88.

Sertkaya G, Martini M, Musetti R, Osler R (2007) Detection and molecular characterization of phytoplasmas infecting sesame and solanaceous crops in Turkey. Bulletin of Insectology 60: |4I-142.

Özdemir Z, Topuz H, Çağırgan MI (20I3) Identification of sesame phyllody phytoplasmas and incidence of sesame phyllody disease in Antalya, Turkey. Acta Phytopathologica Sinica, 43: 204.

Özdemir Z, Topuz H, Erler F, Çağırgan Mi (20l4) Antalya ili susam alanlarından toplanan Orosius orientalis (Matsumura) (Homoptera: Cicadellidae)'lerde 'Candidatus Phytoplasma australasla'nın tespiti, V. Bitki Koruma Kongresi, Antalya.

Özdemir Z (2017) Phytoplasmas of sesame and Orosius orientalis are genetically diverse based on I6S rDNA sequencing and PCR-RFLP in Turkey. Archives of Phytopathology and Plant Protection 50: 674-686.

Seçer A (2016) Türkiye'de susam üretim ve dıș ticaretinde gelișmeler. Çukurova Tarım ve Gıda Bilimleri Dergisi 3I: 27-36.

Tan AȘ (20I5). Susam tarımı. T.C Gıda Tarım ve Hayvancılık Bakanlığı. Ege Tarımsal Araștırma Enstitüsü. Yayın No: I35. Menemen, İzmir. 